TATA LOKA

Volume 15 Nomor 2, MeI 2013, 91-101

\title{
PASAR: SIMPUL PERSEBARAN BUDAYA DI KABUPATEN BANTUL, DAERAH ISTIMEWA YOGYAKARTA
}

\author{
Market: A Node Of Cultural Spread In Bantul Regency, Yogyakarta \\ Special Region
}

\section{Endy Marlina ${ }^{1}$, Arya Roland ${ }^{2}$, Sudaryono², dan Atyanto Dharoko²}

Diterima : 22 Maret 2012 Disetujui: 6 Maret 2013

\begin{abstract}
Abstrak: Tujuan penelitian ini untuk mengungkapkan nilai-nilai yang mendasari penciptaan dan pengembangan pasar di Kabupaten Bantul berdasarkan konsep ruang dilihat sebagai ruang (bentuk fisik yang bisa dilihat secara visual) dan sebagai tempat (wadah kegiatan manusia yang mungkin mencerminkan nilai-nilai budaya dari pengguna mereka). Penelitian ini menggunakan paradigma fenomenologi dan ditemukan bahwa mobilisasi ekonomi sebagai suatu sistem dalam masyarakat Jawa di Kabupaten Bantul yang diwarnai dengan relasi sosial secara dominan membangun pasar sebagai ruang sosioekonomi. Pasar sebagai wadah kegiatan ekonomi berperan sebagai simpul jaringan sosial masyarakat dan merupakan media penting dalam penyebaran budaya. Nilai budaya yang mendasari praktik kehidupan masyarakat pasar adalah kebersamaan, kemitraan, kesopanan, dan kerukunan dan merupakan kearifan lokal masyarakat Kabupaten Bantul yang mampu menjaga keberlanjutan sistem pekenan - sistem mobilisasi - kegiatan ekonomi di Kabupaten Bantul.
\end{abstract}

\section{Kata kunci: kebersamaan, kemitraan, kerukunan, kesopanan, mobilisasi kegiatan ekonomi}

Abstract: The study which aimed to uncover the values underlying the creation and development of the market in Bantul regency is base on the idea that space can be viewed as a space (physical form that can be seen visually) and as a place (the container of human activities that may reflect cultural values of the user them). This study was conducted with the paradigm of phenomenology and found that pekenan as a mobilization system of economic in the Javanese community in the district of Bantul, dominated by social values that develop a market as a socioeconomic space. Market as an economic activity container has a major role as a social networking nodes and important node in order to disseminate of culture in the district of Bantul. This study also found that the cultural values underlying the economic activity in the market is togetherness, partnership, civility, and harmony, they are local wisdoms of the people which are able to maintain the sustainability of the system of pekenan - mobilization system of the economic activity in the district of Bantul.

Key words: togetherness, partnership, harmony, civility, the mobilization of economic activity

\footnotetext{
${ }^{1}$ Program Studi Arsitektur, Fakultas Sains dan Teknologi, Universitas Teknologi Yogyakarta Jl. Ringroad Utara, Jombor, Sleman, Yogyakarta 55285

${ }^{2}$ Jurusan Teknik Arsitektur dan Perencanaan, Fakultas Teknik, Universitas Gadjah Mada Jl. Grafika 2, Sekip, Yogyakarta, 55281
}

Korespondensi: endy_marlina@yahoo.com 


\section{Pendahuluan}

Ruang dan manusia, satu dengan lainnya saling berhubungan dan saling mempengaruhi. Hubungan ini membangun keterkaitan dialektik antara ruang dan manusia penggunanya. Dalam konteks ini, ruang tidak saja dilihat sebagai space, tetapi juga sebagai place, yang mencakup kompleksitas fisik dan psikologis. Ruang mengandung makna dan nilai yang tanggapan atau reaksi penggunanya akan bergantung pada latar belakang budaya dan tata nilai yang dimiliki pengguna tersebut. Pendekatan ini melihat ruang dalam kaitannya dengan aspek norma, budaya, dan psikologis masyarakat. Sebagai space, ruang merupakan bentukan fisik yang dapat dilihat secara visual, sedangkan sebagai place ruang merupakan wadah kegiatan manusia yang dapat merefleksikan tata nilai dan budaya penggunanya (Schulz, 1977). Setelah diciptakan, ruang akan tumbuh dan berkembang bersama dengan manusia yang menghuninya (Habraken, 1998). Aktivitas inilah yang kemudian memberi nafas, makna, dan nilai pada ruang tersebut.

Dalam cakupan yang lebih luas, keterkaitan antara ruang dan masyarakat penggunanya akan mengembangkan berbagai tatanan ruang secara lebih luas pula. Hal ini merupakan perwujudan tanggapan masyarakat terhadap ruang yang mengakomodir latar budaya masyarakat tersebut.

Keterkaitan antara berbagai perilaku manusia di dalam ruang membentuk sistem kegiatan yang mengkaitkan tiga aspek yaitu tatanan fisik, tatanan sosial, dan aktivitas manusia. Dalam hubungan ini aktivitas manusia merupakan komponen subyek yang dapat mengendalikan tatanan fisik dan tatanan sosial di sekitarnya, meskipun tidak dapat dipungkiri bahwa tatanan fisik dan sosial juga dapat mempengaruhi aktivitas manusia, namun pada dasarnya manusia adalah komponen yang mempunyai kuasa untuk mengendalikan komponen lainnya (Lawson, 2001). Adanya komponen manusia dalam tautan ini menghadirkan pemahaman adanya 'pemikiran' di dalam penelitian yang menggunakan pendekatan perilaku. Sebagai mahkluk berakal, manusia mempunyai pendapat dan pemikiran dalam merespon lingkungan fisik dan sosialnya.

Penilaian individu terhadap lingkungannya yang merupakan interpretasi tentang suatu seting oleh individu, didasarkan latar belakang budaya, nalar, dan pengalaman individu tersebut (Haryadi, 1995). Penilaian ini melibatkan 5 indera manusia (Lawson, 2001). Berdasarkan penilaian ini, ruang hidup manusia dapat dibagi dalam 3 tingkatan (Kuo \& Minami, 2009) yaitu: dirrect contact space (tingkatan ruang yang memungkinkan terjadinya kontak langsung dengan melibatkan 5 indera), the environmental affordance level (tingkatan ruang yang dapat dijangkau), dan the cognitive image level (tingkatan ruang yang dapat dikenali melalui penggambaran secara kognitif). Latar pengetahuan di atas digunakan dalam penelitian tentang kegiatan ekonomi di pasar di Pasar di Kabupaten Bantul, Daerah Istimewa Yogyakarta, Indonesia.

Sebagai refleksi tata nilai dan budaya penggunanya, pembentukan dan penggunaan pasar ini menggambarkan pengaruh kegiatan ekonomi pada ruang tersebut dan sebaliknya, pengaruh ruang terhadap kegiatan penggunanya. Pada dasarnya, pasar dapat dipandang sebagai refleksi psikologis, sosial, dan kultural masyarakat penggunanya (dikembangkan dari Lawson, 2001). Dalam hal ini, pemanfaatan pasar dapat dikaji meliputi berbagai bentuknya yaitu sistem gagasan, tindakan, dan wujud ruang itu sendiri sebagai hasil karya manusia dalam kehidupannya (Koentjaraningrat, 1996). Bertahannya sektor ekonomi rakyat di Kabupaten Bantul patut dikaji secara mendalam untuk mengungkapkan budaya dan tata nilai lokal yang terbukti mampu menjaga keberlanjutan kehidupan masyarakat khususnya golongan ekonomi lemah 


\section{Metodologi}

Adanya keterlibatan budaya, nalar, dan pengalaman individu dalam penilaian terhadap ruang memberikan konsekuensi dalam penelitian ini yaitu diperlukannya wawancara secara mendalam untuk mengungkapkan ide, gagasan, serta dasar pemikiran yang ada dibalik penilaian yang diberikan oleh individu terhadap ruang. Penggalian secara mendalam ini dimungkinkan apabila penelitian dilakukan dengan menyatukan subyek dan obyek penelitian. Berdasarkan pertimbangan ini, dalam penelitian ini digunakan paradigma fenomenologi sebagai metode deskriptif dengan sistematika yang ketat (rigorous) untuk menjelaskan mengenai fenomena yang dikenal oleh kesadaran secara langsung (Siregar, 2005). Secara harfiah fenomenologi adalah aliran atau faham yang menganggap bahwa fenomena (gejala) adalah sumber pengetahuan dan kebenaran (Maksum, 2008). Menurut Husserl, esensi pada pemikiran fenomenologi selalu mengacu pada perikehidupan manusia, merupakan studi tentang kebudayaan/'jiwa' kebudayaan pada dasar pijakan yang betulbetul ilmiah (Welton, Donn, 1999; Lincourt, Michel, 1999).

Kegiatan ekonomi di pasar dilihat sebagai satu kesatuan fenomena. Kegiatan ekonomi ini juga dipandang sebagai suatu sistem, dalam arti mempunyai keterkaitan dengan berbagai kegiatan lain. Sistem ini mempunyai tiga komponen yaitu pelaku, ruang, dan kegiatan yang dilakukan di dalam lingkungan pasar. Penyebutan 'sistem' pada kegiatan ekonomi ini juga untuk menggambarkan adanya keterkaitan antara ketiga komponen tersebut. Dalam penelitian ini, fenomena diobservasi sesuai dengan konteks lingkungannya secara mendalam untuk menangkap esensi/hakikatnya. Hal ini ditujukan untuk mengungkapkan tata nilai yang mendasari terbentuknya sistem peruangan pasar di Kabupaten Bantul, Yogyakarta, Indonesia, saat ini.

Pertama, penelitian ini mengobservasi pembentukan dan perkembangan tatanan ruang di pasar. Observasi ini mengkaitkan tiga tatanan yaitu tatanan fisik, tatanan sosial, dan tatanan aktifitas para pengguna ruang. Observasi tatanan fisik dalam kegiatan ekonomi rakyat mencakup tatanan ruang perorangan maupun tatanan kelompok ruang di pasar; observasi tatanan sosial mencakup hubungan dan tatanan antara para pengguna ruang yang terdiri dari penjual, pembeli, pengelola pasar, pemasok barang, dan masyarakat sekitar; sedangkan observasi tatanan aktivitas mencakup berbagai aktivitas yang dilakukan oleh pengguna pasar.

Kedua, observasi tentang tatanan pasar sebagai setting kegiatan ekonomi rakyat dilakukan dengan memandang kegiatan ekonomi rakyat sebagai suatu sistem. Penggunaan kata sistem dimaksudkan untuk memberikan gambaran adanya keterkaitan antara kegiatan ekonomi dengan kegiatan lainnya dalam kehidupan sehari-hari masyarakat; dan adanya keterkaitan antara ketiga tatanan yang terkait di dalamnya. Pengamatan dan penggalian fenomena lapangan dilakukan secara intensif untuk menjaring informasi secara maksimal dan dapat mereduksinya untuk menemukan esensi kegiatan ekonomi rakyat itu sendiri, keterkaitannya dengan ruang yang mewadahinya, hingga keterkaitannya dengan lingkungan yang lebih luas. Penggalian informasi dilakukan dengan cara mempertanyakan segala sesuatu fenomena yang tampil ke hadapan subyek.

\section{Hasil dan Pembahasan}

Kabupaten Bantul adalah sebuah kabupaten di Provinsi Daerah Istimewa Yogyakarta, Indonesia. Ibu kotanya adalah Bantul. Kabupaten ini berbatasan dengan Kota Yogyakarta dan Kabupaten Sleman di utara, Kabupaten Gunungkidul di timur, Samudra Hindia di selatan, serta Kabupaten Kulon Progo di barat.

Kabupaten Bantul terdiri atas 17 kecamatan, yang dibagi lagi atas 75 Desa, 933 Dusun. Pusat pemerintahan berada di Kecamatan Bantul, sekitar $11 \mathrm{~km}$ sebelah selatan 
Kota Yogyakarta. Bagian selatan kabupaten ini berupa pegunungan kapur, yakni ujung barat dari Pegunungan Sewu. Pada 27 Mei 2006, gempa bumi besar berkekuatan 5,9 skala Richter mengakibatkan kerusakan yang besar terhadap daerah ini dan kematian sedikitnya 3.000 penduduk Bantul. Daerah terparah akibat gempa adalah Pundong dan Imogiri.

Kabupaten Bantul terletak antara $07^{\circ} 44^{\prime} 04^{\prime \prime}-08^{\circ} 00^{\prime} 27^{\prime \prime}$ Lintang Selatan dan $110^{\circ}$ 12' 34" - $110^{\circ} 31^{\prime}$ 08" Bujur Timur. Luas wilayah Kabupaten Bantul 508,85 Km2 (15,90 \% dari Luas wilayah Propinsi DIY) dengan topografi sebagai dataran rendah $40 \%$ dan lebih dari separonya (60\%) daerah perbukitan yang kurang subur. Wilayah kabupaten ini secara garis besar terdiri dari : a) bagian barat, adalah daerah landai yang kurang subur serta perbukitan yang membujur dari Utara ke Selatan seluas 89,86 km2 (17,73 \% dari seluruh wilayah), b) bagian tengah, adalah daerah datar dan landai merupakan daerah pertanian yang subur seluas $210.94 \mathrm{~km} 2(41,62 \%)$, c) bagian timur, adalah daerah yang landai, miring dan terjal yang keadaannya masih lebih baik dari daerah bagian Barat, seluas 206,05 km2 $(40,65 \%)$, dan d) bagian selatan, adalah sebenarnya merupakan bagian dari daerah bagian Tengah dengan keadaan alamnya yang berpasir dan sedikir berlagun, terbentang di Pantai Selatan dari Kecamatan Srandakan, Sanden dan Kretek.

Jumlah penduduk Kabupaten Bantul sebanyak 789.745 jiwa, terdiri dari penduduk laki-laki sebanyak 386.777 jiwa (48,97\%) dan penduduk perempuan sebanyak 402.968 jiwa (51,03 \%). Rerata laju pertumbuhan penduduknya adalah $0,85 \%$ dan kepadatan saat ini adalah $1.558 \mathrm{jiwa} / \mathrm{km} 2$.

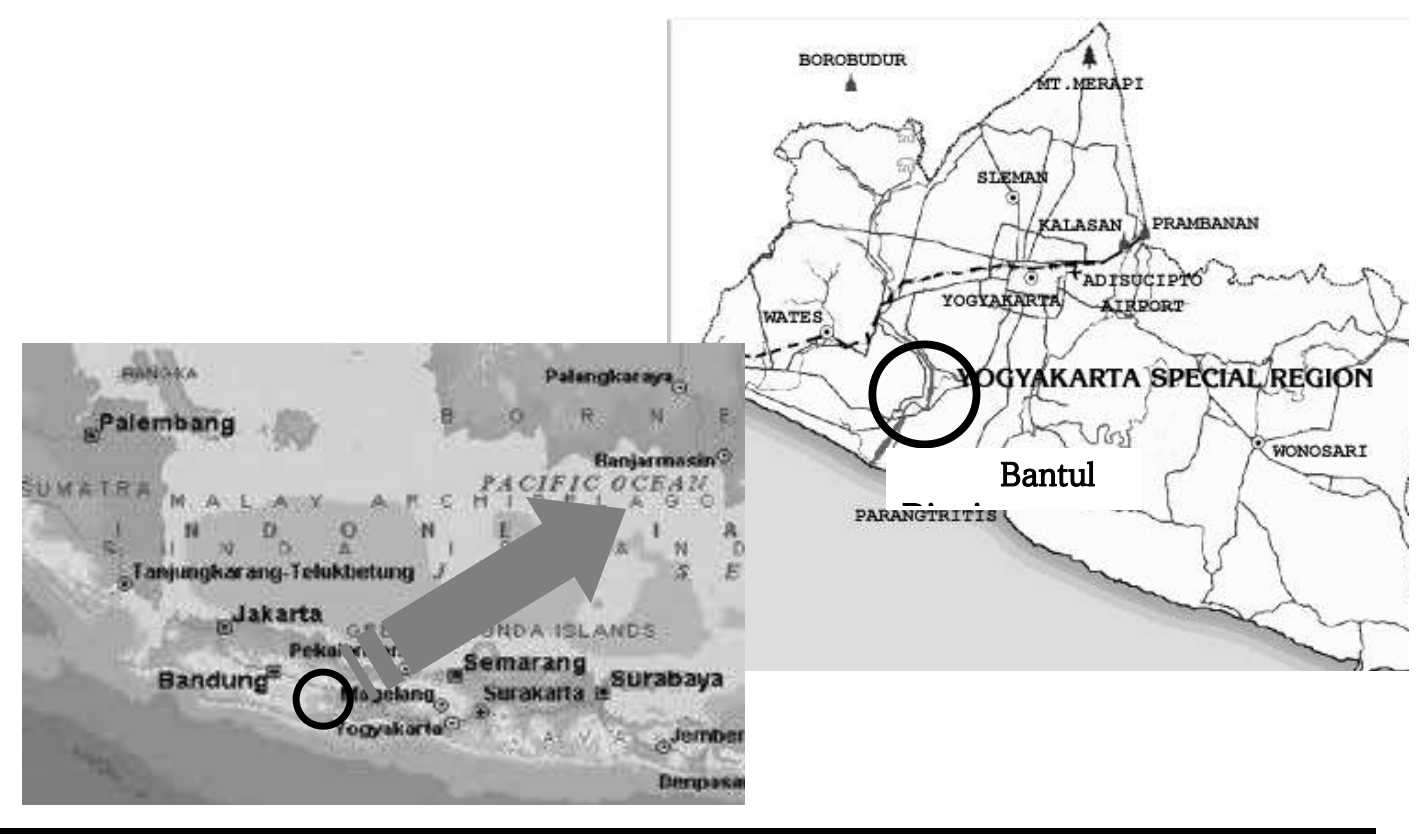

Gambar 1. Lokasi Kabupaten Bantul Di Pulau Jawa, Indonesia

Masyarakat Bantul adalah masyarakat berlatar budaya Jawa. Pemerintahan di Kabupaten Bantul dikelola dengan sistem kerakyatan. Demikian juga sistem perekonomiannya, dikelola dengan sistem ekonomi kerakyatan. Dalam sistem ini, perkembangan perekonomian ditekankan pada sektor perekonomian dominan masyarakat.

Di Kabupaten Bantul, penggerak utama perekonomian adalah sektor pertanian. Sebagian besar transaksi ekonomi dilakukan secara tradisional, dengan wadah kegiatan ekonominya berupa pasar tradisional. Dalam sistem ekonomi kerakyatan ini, tatanan ekonomi dibangun berdasar hubungan saling ketergantungan. Ekonomi kerakyatan 
menganggap efisiensi sebagai prinsip yang bersifat universal, karena ia memecahkan masalah kelangkaan melalui cara kerja sama.

Hingga saat ini, pasar masih merupakan ruang kegiatan ekonomi pilihan kebanyakan masyarakat di Kabupaten Bantul. Sistem kegiatan ekonomi ini menggambarkan pranata perkonomian yang berlaku dalam masyarakat, yang secara spesifik erat kaitannya dengan pranata sosial. Hal ini menggambarkan sistem norma atau aturan-aturan yang menyangkut aktivitas masyarakat dalam kehidupannya (Zoetmulder, dalam Nastiti 2003). Pandangan yang sama disampaikan oleh Koentjaraningrat (1996), bahwa sistem sosial erat kaitannya dengan sistem ekonomi. Keduanya termasuk dalam unsur kebudayaan selain bahasa, organisasi sosial, sistem peralatan hidup dan teknologi, sistem religi, dan kesenian. Hal serupa juga disampaikan sebelumnya oleh Herskovits, dalam Nastiti 2003) bahwa pranata sosial yang mendasari aktivitas masyarakat tidak lepas dari kebudayaan masyarakat tersebut, merupakan wujud dari berbagai respon yang diformulasikan dan disistematisasikan dari segala kebutuhan hidup. Hal ini erat kaitannya dengan religi, perekonomian dan mata pencaharian, kekerabatan, perkawinan, etika, dan kesenian (Hadiatmaja, 2009).
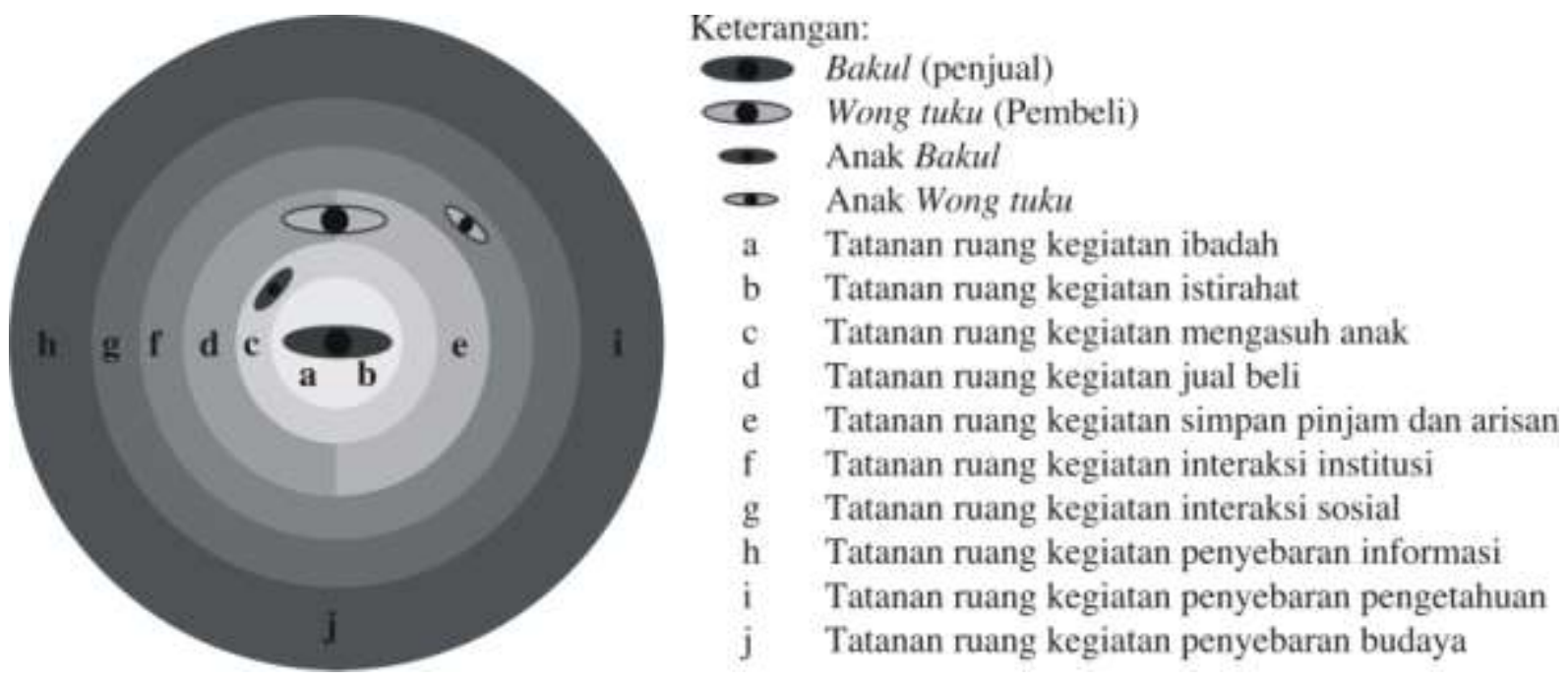

Sumber: Marlina, 2011

\section{Gambar 2. Variasi Tatanan Ruang Yang Berkembang Di Pasar-Pasar Di Kabupaten Bantul}

Pasar sebagai wadah kegiatan ekonomi di Kabupaten Bantul, mengakomodir variasi kegiatan yang lebih kompleks. Selain kegiatan pengelolaan sebagai kegiatan pendukung operasional pasar, berbagai kegiatan lain berkembang dan justru memberikan suasana dan identitas khas pada pasar-pasar di Kabupaten Bantul. Kegiatan ekonomi sekunder seperti simpan pinjam dan arisan berkembang selain dengan orientasi ekonomis juga ditujukan untuk memelihara relasi sosial antara para pengguna pasar. Selain itu, berbagai kegiatan keluarga dan sosial lainnya berkembang dan justru lebih dominan akomodasinya. Lebih lanjut, berbagai kegiatan tersebut membentuk variasi tatanan ruang di pasar. Berdasarkan jenis kegiatannya, gambaran kompleksitas tatanan ruang yang berkembang di pasar-pasar Kabupaten Bantul dapat dilihat pada Gambar 2 (Marlina, 2011).

Merujuk pada pendapat Koentjaraningrat (1996), interaksi unsur budaya antara para pengguna pasar di Kabupaten Bantul ini mencakup sistem gagasan, tindakan, dan hasil 
karyanya. Karenanya, observasi tentang hal ini lebih jauh akan dapat mengungkapkan ide/gagasan yang mendasari kegiatan-kegiatan para pengguna pasar.

Sebagai wadah kegiatan ekonomi, pasar di Kabupaten Bantul tidak saja mengakomodasi kegiatan ekonomi, namun juga sarat dengan kegiatan sosial. Secara umum, kegiatan yang terjadi di pasar mencakup kegiatan jual beli, kegiatan pengelolaan, kegiatan ekonomi sosial (simpan pinjam), dan kegiatan sosioekonomi. Kegiatan terakhir adalah kegiatan sosial yang berkembang bersama dengan kegiatan ekonomi masyarakat pasar yang justru mendominasi dan memberikan suasana khas pasar di Kabupaten Bantul (Marlina, 2010).

Salah satu paham yang berlaku dalam masyarakat Jawa adalah paham 'Ratu Adil' dimana kesejahteraan rakyat merupakan hal yang utama, sebagai realisasi prinsip 'keseimbangan' yang artinya bukan saja keseimbangan politik tetapi juga keseimbangan ekonomi - kesejahteraan bersama sebaik-baiknya (Hadiatmaja, 2009). Dalam sistem kegiatan ekonomi di Kabupaten Bantul, prinsip ini dicapai dengan strategi penyebaran kegiatan ekonomi. Hal ini direalisasikan dengan mobilitas pasar yang dapat menjadi generator perkembangan wilayah di Kabupaten Bantul. Kebanyakan pasar di Kabupaten Bantul mengalami fluktuasi kegiatan ekonomi dengan siklus 5 (lima) harian sesuai dengan penanggalan Jawa (Legi, Paing, Pon, Wage, dan Kliwon). Setiap satu hari dalam lima hari tersebut suatu pasar mempunyai intensitas kegiatan ekonomi tertinggi. Siklus ini oleh masyarakat lokal disebut sebagai 'pekenan/pasaran', yang berasal dari kata 'pasar', untuk menggambarkan waktu terjadinya kegiatan ekonomi di suatu wilayah. Pekenan suatu pasar terjadi pada hari yang berbeda-beda antara satu pasar dengan pasar lainnya. Dengan sistem seperti ini, aktivitas ekonomi akan berputar/berpindah dari satu tempat ke tempat lain, sehingga transaksi ekonomi akan merata di berbagai wilayah (Gambar 3).

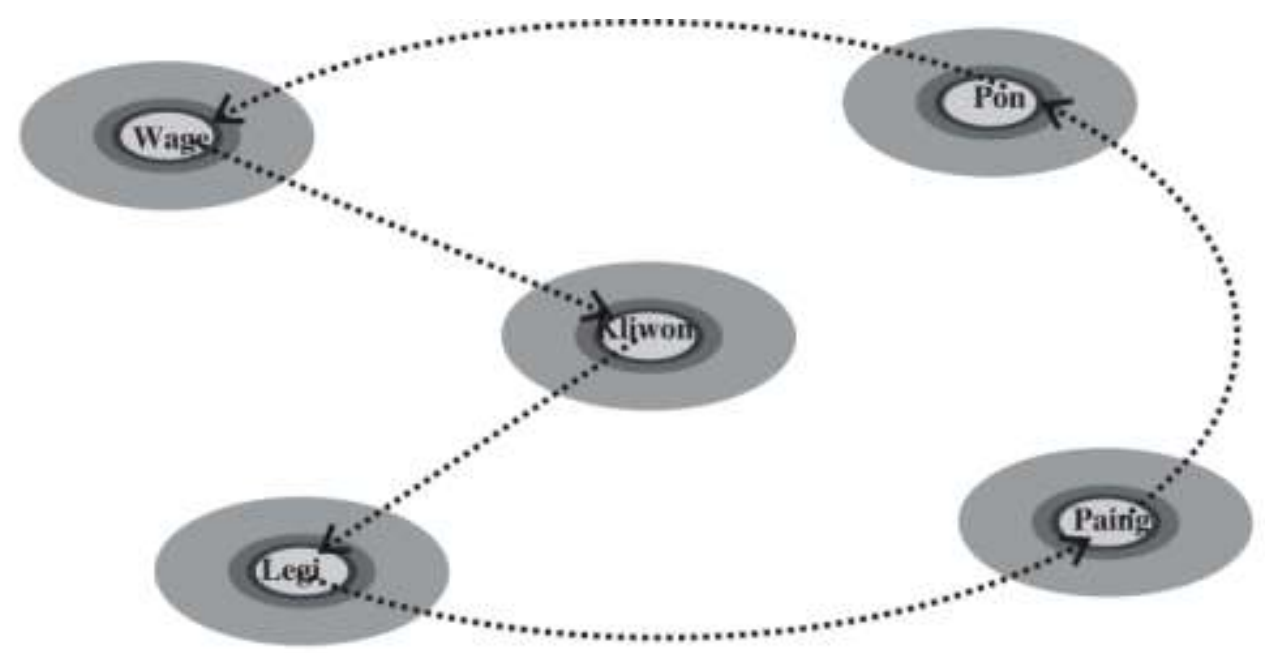

Keterangan:

Kegiatan jual beli

Kegiatan pengelolaan
Kegiatan ekonomi-sosial (simpan pinjam)

Kegiatan sosioekonomi

pergerakan pasar pada sistem pekenan

Gambar 3. Meluasnya Jaringan Kegiatan Ekonomi Berdampak Pada Meluasnya Pertumbuhan Wilayah Yang Diawali Dari Lokasi-Lokasi Pasar Dalam Sistem Pekenan. 
Berkembangnya kegiatan ekonomi di suatu tempat tentunya tidak secara tiba-tiba terjadi dalam skala yang besar, namun mengalami proses pertumbuhan yang mencerminkan pertumbuhan suatu wilayah. Dukungan yang kuat mengakibatkan cepatnya perkembangan suatu pasar.

Secara umum masyarakat mengimplementasikan pranata ekonomi dengan tujuan untuk mencapai kesejahteraan bagi anggota-anggotanya. Hubungan-hubungan dalam masyarakat pada dasarnya merupakan pengejawantahan hubungan-hubungan antar manusia. Dalam konteks kegiatan ekonomi, hubungan ini tampak dalam hubungan antara pedagang-pembeli-pengelola, serta dalam hubungan antar pedagang, antar pembeli, dan antar pengelola.

Lebih luas lagi, hubungan ini kemudian berkembang mencakup lingkup institusi, hubungan antar keluarga pedagang, antar keluarga pembeli, antar keluarga pengelola, maupun hubungan antara anggota keluarga pedagang-pembeli-pengelola. Dalam interaksi antara para pengguna pasar di Kabupaten Bantul, terjadi interaksi dan distribusi informasi dan pengetahuan yang merupakan unsur kebudayaan. Artinya, dalam interaksi antara para pengguna pasar di Kabupaten Bantul terjadi interaksi dan distribusi budaya masyarakat pasar. Berdasarkan wujudnya, sebagian besar interaksi dan distribusi budaya ini terjadi dalam wujud interaksi sosial. Kentalnya relasi sosial yang berkembang bersama kegiatan ekonomi di pasar Kabupaten Bantul mampu membangun peranan pasar sebagai media distribusi informasi, ilmu pengetahuan, dan budaya. Perputaran pasar dalam sistem pekenan kemudian membentuk berbagai sistem sebagai berikut (Gambar 4).

1. Sistem informasi pekenan

Dalam interaksi antara pedagang - pembeli - pengelola pasar serta interaksi antar pedagang, antar pembeli, dan antar pengelola, terjadi perpindahan informasi. Informasi yang berpindah dapat berasal dari pasar itu sendiri maupun dari rumah/desa asal para pelaku ekonomi tersebut. Mobilitas para pelaku kegiatan ekonomi dari satu tempat ke tempat lain dalam sistem pekenan kemudian membentuk jaringan informasi yang lebih luas, sistem informasi pekenan.

2. Sistem pengetahuan pekenan

Interaksi antara manusia dari berbagai latar budaya dengan berbagai latar pengetahuan diikuti dengan terjadinya pertukaran pengetahuan. Masyarakat yang berinteraksi dalam kegiatan ekonomi di pasar-pasar di Kabupaten Bantul berasal dari berbagai latar belakang, latar ekonomi, karakter, dan budaya yang berbeda-beda. Interaksi antar para pelaku kegiatan ekonomi ini juga terjadi antara masyarakat dengan ketrampilan dan pengetahuan yang berbeda. Interaksi ini diikuti oleh interaksi sosial, budaya, dan pertukaran pengetahuan antar para pelakunya. Mobilitas para pelaku kegiatan ekonomi dari satu tempat ke tempat lain dalam sistem pekenan kemudian membentuk jaringan pengetahuan yang lebih luas, sistem pengetahuan pekenan.

3. Sistem budaya pekenan

Mobilitas para pelaku kegiatan di pasar di Kabupaten Bantul berdampak pada terjadinya penyebaran dan akulturasi budaya masyarakat. Para pelaku kegiatan ekonomi adalah manusia yang masing-masing memiliki latar budaya. Pada awalnya memang para pelaku kegiatan ekonomi ini seluruhnya adalah masyarakat Jawa. Namun dalam perkembangannya, kegiatan ini meluas melibatkan para pelaku ekonomi dari berbagai latar budaya yang berbeda-beda. Sistem pekenan mengakibatkan terjadinya perputaran kegiatan ekonomi, berdampak pada terjadinya perputaran para pelaku kegiatan ekonomi tersebut. Perputaran ini mengakibatkan terjadinya interaksi antar budaya antara satu pasar dengan pasar lainnya membentuk sistem budaya pekenan. 
Perputaran pasar dalam sistem pekenan mengakibatkan terjadinya pergerakan kegiatan ekonomi dengan segala muatan budaya dan ekonominya. Interaksi antara para pelaku kegiatan di pasar ini mengakibatkan terjadinya interaksi budaya antara satu individu dengan lainnya. Hal ini sesuai dengan pendapat Rapoport (1990) bahwa pasar sebagai lingkungan fisik dapat memberikan kesempatan atau hambatan terhadap tingkah laku para penggunanya. Dalam hal ini, pasar mengembangkan relasi ekonomi, relasi sosial, dan relasi budaya antara para penggunanya. Interaksi antara para pengguna ruang (manusia) dengan pasar (lingkungan) ini dipengaruhi oleh latar budaya manusia tersebut. Dengan demikian, pergerakan kegiatan ekonomi ini membangun pergerakan budaya masyarakat di Kabupaten Bantul.

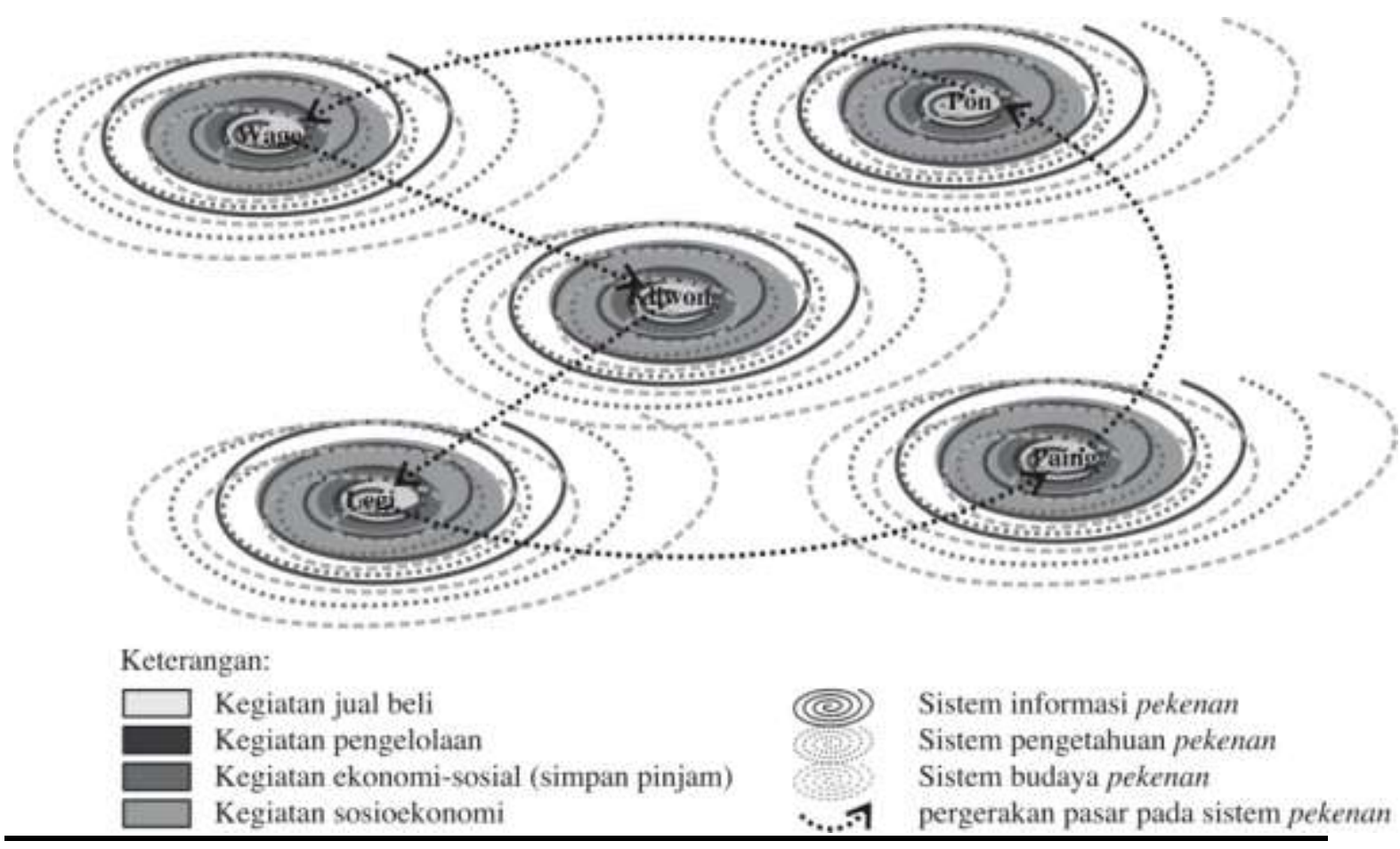

Gambar 4. Sistem Informasi Pekenan, Sistem Pengetahuan Pekenan, Dan Sistem Budaya Pekenan Yang Berkembang Dalam Pergerakan Pasar Pada Sistem Pekenan

Berdasarkan wujudnya, kebudayaan mencakup artefak (benda-benda fisik), sistem tingkah laku/sistem sosial, sistem gagasan, dan sistem gagasan yang ideologis/nilai-nilai budaya. Dalam konteks budaya, perputaran pasar dalam sistem pekenan mengembangkan interaksi dan distribusi budaya yang mencakup semua unsurnya. Dengan demikian, perputaran unsur-unsur budaya ini secara umum dapat digambarkan seperti Gambar 5.

\section{Kesimpulan}

Inti dari lingkaran kebudayaan adalah nilai budaya (Koentjaraningrat, 1996). Nilai budaya merupakan ajaran budaya inti yang mempengaruhi tumbuhnya ide/gagasan, seluruh praktik tingkah laku manusia, dan berkembangnya karya fisik budaya. Tiga hal mendasar yang yang merupakan nilai budaya masyarakat Jawa adalah menjunjung kebersamaan, suka kemitraan, dan mementingkan kesopanan (Anshoriy dan Sudarsono, 
2008). Nilai-nilai ini mendasari berbagai praktik kegiatan yang berkembang di pasar-pasar di Kabupaten Bantul yang kemudian membangun berbagai tatanan fisik (Gambar 2). Hal serupa dinyatakan oleh Marlina (2010) bahwa nilai yang mendasari berbagai praktik kegiatan di pasar-pasar di Kabupaten Bantul dan Gunungkidul pasca gempa Mei 2006 adalah prinsip rukun.

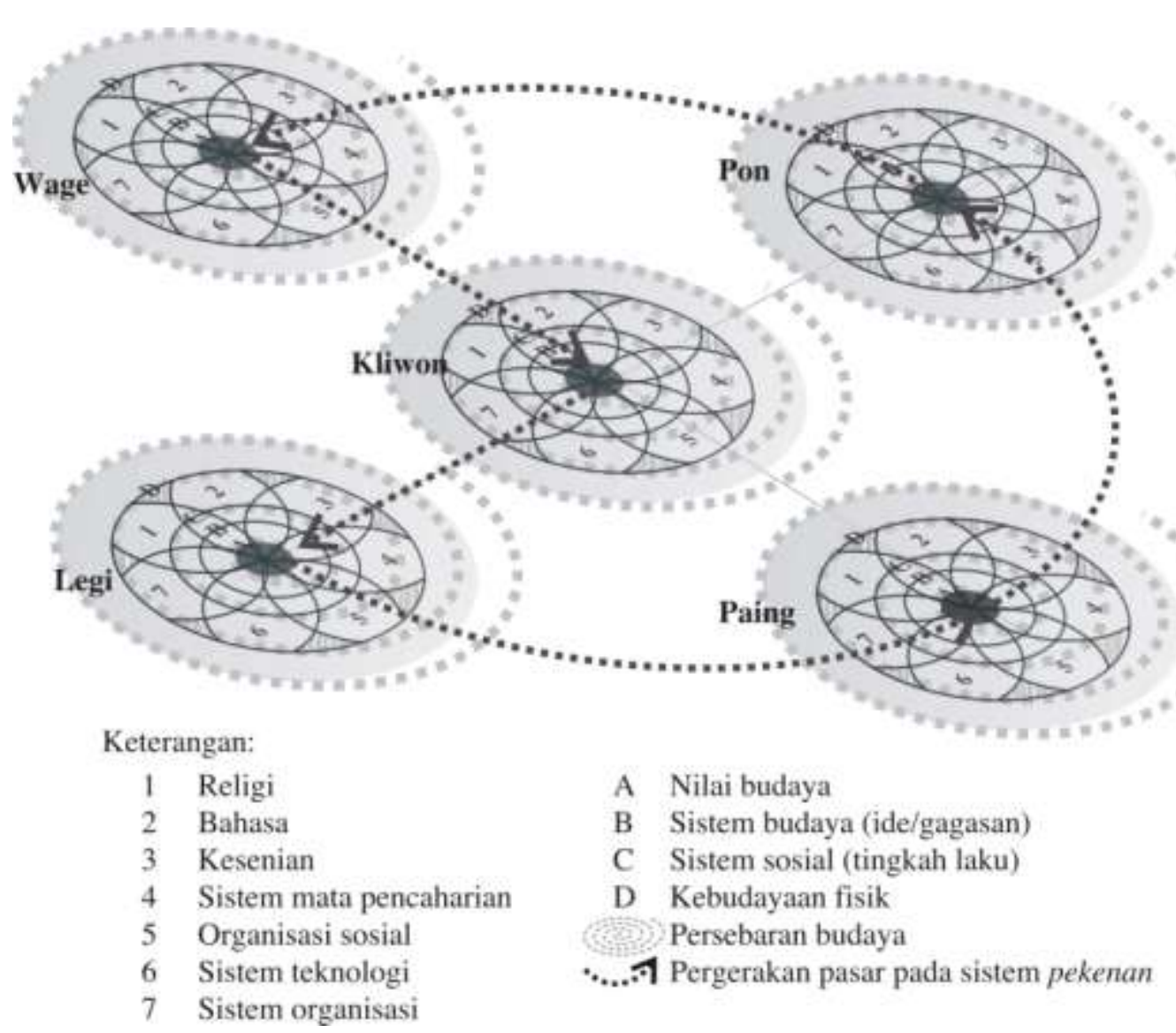

\section{Gambar 5. Persebaran Budaya Dalam Pergerakan Pasar ( Pekenan)}

Nilai-nilai kebersamaan, kemitraan, kesopanan, dan kerukunan merupakan nilai budaya yang mendasari berbagai kegiatan masyarakat, termasuk di dalamnya mendasari praktik kegiatan ekonomi di pasar. Hal ini memberikan keterkaitan logis bahwa kegiatan yang berkembang di pasar-pasar di Kabupaten Bantul didominasi oleh kegiatan sosial. Dengan demikian, pasar bagi masyarakat Jawa di Kabupaten Bantul bukanlah merupakan ruang ekonomi, namun pasar merupakan ruang sosioekonomi.

Sistem pekenan pada kegiatan ekonomi di Kabupaten Bantul mengakibatkan terjadinya perputaran kegiatan dan para pelaku kegiatan ekonomi dari pasar satu ke pasar lainnya sesuai dengan penanggalan Jawa. Perputaran kegiatan ekonomi rakyat ini tidak hanya terjadi terbatas pada 1 siklus pekenan (lima pasar) saja, namun mencakup juga siklus pekenan (pasar-pasar) lain. Hal ini berkembang karena lingkaran pekenan satu dan lainnya saling bertumpangan, sehingga sistem pekenan yang ada berkembang menjadi sistem multi pekenan. 


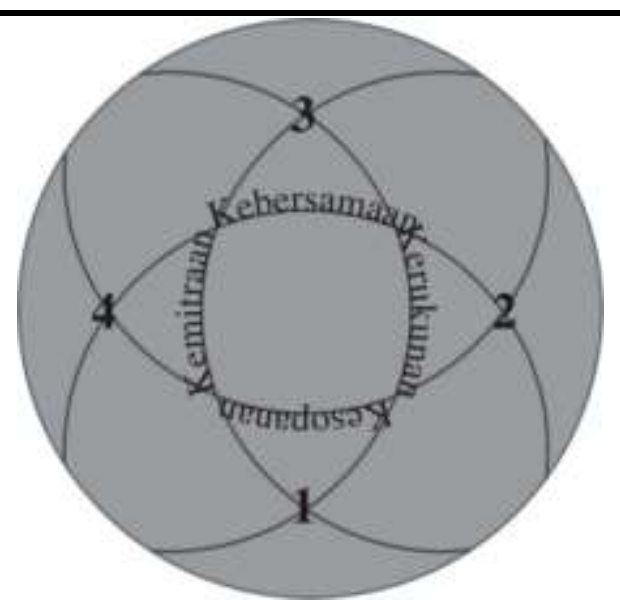

Gambar 6. Nilai-Nilai Budaya Yang Mendasari Praktik Kegiatan Masyarakat

Gambar 7. Persebaran Nilai Budaya Dalam Pergerakan Pasar ( Pekenan) Di Kabupaten Bantul

Selain mengembangkan dan meratakan kegiatan ekonomi, sistem pekenan juga mengembangkan sistem-sistem yang merupakan sistem sosial masyarakat. Dalam konteks Kabupaten Bantul, justru perkembangan sistem sosial masyarakat lebih dominan sebagai dampak dari sistem pekenan. Dalam hal ini, pasar merupakan simpul sosial dalam perkembangan budaya masyarakat Kabupaten Bantul. Pemanfaatan pasar sebagai simpul sosial secara nyata dapat dilihat dalam perkembangan berbagai jaringan yaitu: 1) Sistem pekenan berperan sebagai jaringan kebersamaan (misalnya dalam penyebaran informasi dan komunikasi social); 2) Sistem pekenan berperan sebagai jaringan kemitraan (misalnya dalam penyebaran pengetahuan, perluasan hubungan kekeluargaan); 3) Sistem pekenan berperan sebagai jaringan kesopanan (misalnya dalam pengembangan budaya, perluasan relasi sosial); dan 4) Sistem pekenan berperan sebagai jaringan kerukunan (misalnya dalam perluasan jaringan gotong royong). 


\section{Ucapan Terima Kasih}

\section{Direktorat Pendidikan Tinggi, Kementerian Pendidikan Nasional (Program Hibah Disertasi Doktor)}

\section{Daftar Pustaka}

Anshoriy, dan Sudarsono, 2008, Kearifan Lingkungan Dalam Perspektif Budaya Jawa, Jakarta: Yayasan Obor Indonesia

Habraken, 1998, The Structure of the Ordinary: Form and Control in the Built Environment, USA: Graphic Composition Inc.

Hadiatmaja, S., 2009, Pranata Sosial Dalam Masyarakat Jawa, Yogyakarta: Grafika Indah.

Haryadi, dan Setiawan, B., 1995, Arsitektur Lingkungan dan Perilaku, Yogyakarta: Departemen Pendidikan dan Kebudayaan.

Koentjaraningrat, 1996, Pengantar Ilmu Antropologi, Jakarta: PT Rineka Cipta.

Kuo, Wei-Lun and Minami, Hirofumi, 2009, Is Shopping Street a Larger Unit of Behavior Setting? From a Case Study of The National Market Area, B \& C Street, in Pusan, Korea, Journal of Habitat Engineering, Vol 1.

Lawson, B., 2001, The Language of Space, London: Architectural Press.

Lincourt, M., 1999, In Seacrh of Elegance, Toward an Architecture Satisfaction, London: McGill-Queen's University Press.

Maksum, A., 2008, Pengantar Filsafat: Dari Masa Klasik Hingga Postmodernisme, Yogyakarta: Ar-Ruzz Media.

Marlina, E., 2011 Mukti Siji Mukti Kabeh - Paham Keseimbangan Dalam Sistem Kegiatan Ekonomi Rakyat, Yogyakarta: Program Pascasarjana UGM.

Marlina, E., 2010 Rukun: Kearifan Lokal Jawa yang Membimbing Pemulihan Masyarakat Pasca Gempa Mei 2006, Jurnal Sosiohumaniora Vol 12 No 3, Desember 2010,

Marlina, E., 2007, Perubahan Ruang Ekonomi Rakyat Pasca Gempa Yogyakrta Mei 2006, Kasus: Pasar Wonosari, Pasar Piyungan, dan Pasar Bantul, DIY, Yogyakarta: Program Pascasarjana UGM.

Nastiti, Surti, 2003, Pasar di Jawa Masa Mataram Kuna, Jakarta: PT Dunia Pustaka Jaya

Rapoport, A., 1990, System of Activities and System of Setting, Cambridge: Cambridge University Press.

Schulz, C., 1977, The Intention in Architecture, New York: Rizolli.

Siregar, L. G., 2005, Menyingkap Subyektivitas Fenomena, Jakarta: Penerbit Universitas Indonesia.

Van de Ven, C., 1987, Space in Architecture, Van Gorcum \& Comp.

Welton, D., 1999, The Essential Husserl, Indiana: Indiana Unversity Press. 